Abstract

\title{
Investigation of the Effects of Paclitaxel and Pycnogenol on Inflammatory Response (PTX3, BDNF, IGF2R) in Human Breast Cancer Cell Line ${ }^{\dagger}$
}

\author{
Hülya Birinci 1,*, Büşra Şen ${ }^{1}$, Suna Sayğgllı ${ }^{1}$, Ercüment Ölmez ${ }^{2}$, Sevinç İnan ${ }^{3}$ and \\ Kemal Özbilgin ${ }^{1}$ \\ 1 Department of Histology and Embryology, Faculty of Medicine, Celal Bayar University, \\ Manisa 45140, Turkey \\ 2 Department of Pharmacology, Faculty of Medicine, Celal Bayar University, Manisa 45140, Turkey \\ 3 Department of Histology and Embryology, Faculty of Medicine, İzmir Economy University, \\ İzmir 35330, Turkey \\ * Correspondence: hulya_brnc89@hotmail.com; Tel.: +90-05077220929 \\ + Presented at the 2nd International Conference on Natural Products for Cancer Prevention and Therapy, \\ Kayseri, Turkey, 8-11 November 2017.
}

Publish: 14 November 2017

\begin{abstract}
Breast cancer is the most frequently diagnosed cancer among women internationally and the second cause of cancer-related death. Paclitaxel is antitumorigenic agent used for several types tumors, especially in breast cancer treatment. Herbal-derived medicines have introduced as sources of novel drugs due to minimum systemic side effects. Pycnogenol is an extract of the French maritime pine bark and is a naturally occurring compound that is well-tolerated with a high oral bioavailability. It has been highly studied for the treatment of many diseases including cancer. In this study, we aimed to determine the effects of pycnogenol and paclitaxel in MCF-7 breast cancer cells. We designed 3 experimental groups including control, pcynogenol and paclitaxel groups. Paclitaxel and pycnogenol were used in dosage of $0.5 \mu \mathrm{M}$ and $20 \mu \mathrm{g} / \mathrm{mL}$, respectively. After $24 \mathrm{~h}$, immunostainings of PTX3, BDNF, IGF2R, the inflammatory proteins that play roles in tumorigenesis, were done. According to results, paclitaxel group was showed higher expression for all antibodies compared with control and pcynogenol groups. The pcynogenol group showed also higher expression than control group but not like paclitaxel group. As a conclusion, we suggest that pcynogenol may be as an antitumorigenic agent as paclitaxel or may be used with combined drug therapy.
\end{abstract}

Keywords: Breast cancer; inflammation; paclitaxel; pycnogenol

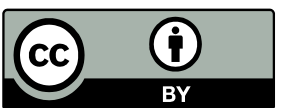

(C) 2017 by the authors. Licensee MDPI, Basel, Switzerland. This article is an open access article distributed under the terms and conditions of the Creative Commons Attribution (CC BY) license (http://creativecommons.org/licenses/by/4.0/). 